\title{
Immobilization of Enzymes on Poly(acrylic acid)-attached Magnetite Particles
}

\author{
Masato Shimomura, Norimiki SugiYama, Takeshi Yamauchi, \\ and Shinnosuke MiYAUCHI \\ Department of Bioengineering, Faculty of Engineering, \\ Nagaoka University of Technology, 1603-1, \\ Kamitomioka-cho, Nagaoka 940-2188, Japan
}

(Received September 25, 1997)

KEY WORDS Poly(acrylic acid) / Redox Polymerization / Magnetite / Enzyme / Immobilization /

Enzymes have been utilized by immobilization on supports such as inorganic materials. ${ }^{1-3}$ Magnetic supportmaterials are useful in reactor application, i.e., enzymes immobilized on magnetic particles can be transported to a reactor or recovered from a reaction mixture magnetically.

The authors reported covalent immobilization of glucose oxidase on magnetite particles. ${ }^{4,5}$ The immobilization includes polymerization of acrylic acid from the surface of magnetite particles initiated by redox reaction between mercapto groups introduced on the surface and ceric ions, and condensation reaction of glucose oxidase with carboxyl groups of the poly(acrylic acid) on the surface. The glucose oxidase on the magnetite particles retained $c a .50 \%$ activity of the native enzyme and kept $95 \%$ the original activity in water over a period of 9 months. The present communication reports the immobilization of enzymes having various molecular sizes. $\alpha$-Chymotrypsin, peroxidase, catalase and urease, in addition to glucose oxidase, were immobilized on the poly(acrylic acid)-attached magnetite particles, and the amounts and activities of the immobilized enzymes were measured.

\section{EXPERIMENTAL}

The magnetite used was MAT-305 obtained from Toda Kogyo Corp. in the form of spherical particles. The magnetite had an average particle size of $0.23 \mu \mathrm{m}$ and a BET surface area of $7.2 \mathrm{~m}^{2} \mathrm{~g}^{-1}$. $\alpha$-Chymotrypsin (EC 3.4.21.1) was supplied by Worthing Biochemical Corp., and had an activity of $50 \mathrm{U} \mathrm{mg}^{-1}$. Peroxidase (EC 1.11.1.7) and catalase (EC 1.11.1.6) were supplied by Sigma Chemical Co., and had activities of $87 \mathrm{U} \mathrm{mg}^{-1}$ and $41000 \mathrm{U} \mathrm{mg}^{-1}$, respectively. Urease (EC 3.5.1.5) and glucose oxidase (EC 1.1.3.4) were from Toyobo Co., Ltd. with activities of $119 \mathrm{U} \mathrm{mg}^{-1}$ and $164 \mathrm{U} \mathrm{mg}^{-1}$, respectively. Acrylic acid from Wako Pure Chemical Ind., Ltd. was distilled under reduced pressure prior to use. 3Mercaptopropyltrimethoxysilane (MPS) from Kanto Chemical Co., Inc. was used without further purification. Other chemicals were of guaranteed-reagent grade or analytical grade and used without further purification.

The magnetite particles were treated with MPS to introduce mercapto groups onto the surface. ${ }^{6}$ Poly(acrylic acid) was attached to the magnetite surface, as described in a previous publication, ${ }^{5}$ by polymerization of acrylic acid initiated by the redox reaction between the mercapto groups on the surface and ceric ions.

The enzymes were immobilized on the magnetite particles attached with poly(acrylic acid) in $0.1 \mathrm{M}$ phosphate buffer solution $(\mathrm{pH} 6.5)$ at room temperature using 1-cyclohexyl-3-(2-morpholinoethyl)-carbodiimide metho- $p$-toluene-sulfonate as a condensing agent according to the method of Mosbach. ${ }^{5,7}$ The amounts of the immobilized enzymes were estimated by analysis with the Folin-Ciocalteu phenol reagent after alkaline copper treatment according to Lowry. ${ }^{8}$

Activity measurements were carried out considering optimum conditions for the native enzymes. The activity of $\alpha$-chymotrypsin was determined by measuring the rate of hydrolysis of $N$-benzoyl-L-tyrosin- $p$-nitroanilide at $37^{\circ} \mathrm{C}, \mathrm{pH}$ 8.0. The activities of peroxidase and catalase were determined by measuring the rate of reduction of hydrogen peroxide at $30^{\circ} \mathrm{C}, \mathrm{pH} 7.0$. The activiy of urease was determined by measuring the rate of decomposition of urea at $25^{\circ} \mathrm{C}, \mathrm{pH} 7.0$. The activity of glucose oxidsase was determined by measuring the rate of $\beta$-D-glucose oxidation at $30^{\circ} \mathrm{C}$, $\mathrm{pH} 7.0 .^{9}$

\section{RESULTS AND DISCUSSION}

After the polymerization of acrylic acid in the redox system at $30^{\circ} \mathrm{C}$ for $1 \mathrm{~h}, 60 \mathrm{mg}$ of poly(acrylic acid) were attached to $1 \mathrm{~g}$ of the magnetite particles employed in the polymerization, followed by enzyme immobilization. Table I shows the amounts of enzymes immobilized on the magnetite. Taking the molecular weight of each enzyme into account, the number of immobilized enzyme molecules related to the molecular weight is shown in

Table I. Amounts of immobilized enzymes

\begin{tabular}{lrc}
\hline & & $\begin{array}{c}\text { Amount of enzyme immobilized } \\
\text { on 1 g magnetite }\end{array}$ \\
\cline { 3 - 3 } Enzyme (Molecular weight) & $\mathrm{mg}$ \\
\cline { 3 - 3 } & & \\
\hline -Chymotrypsin & $(25000)$ & 9.3 \\
Peroxidase & $(40000)$ & 4.4 \\
Glucose oxidase & $(153000)$ & 2.8 \\
Catalase & $(240000)$ & 8.6 \\
Urease & $(480000)$ & 5.2 \\
\hline
\end{tabular}




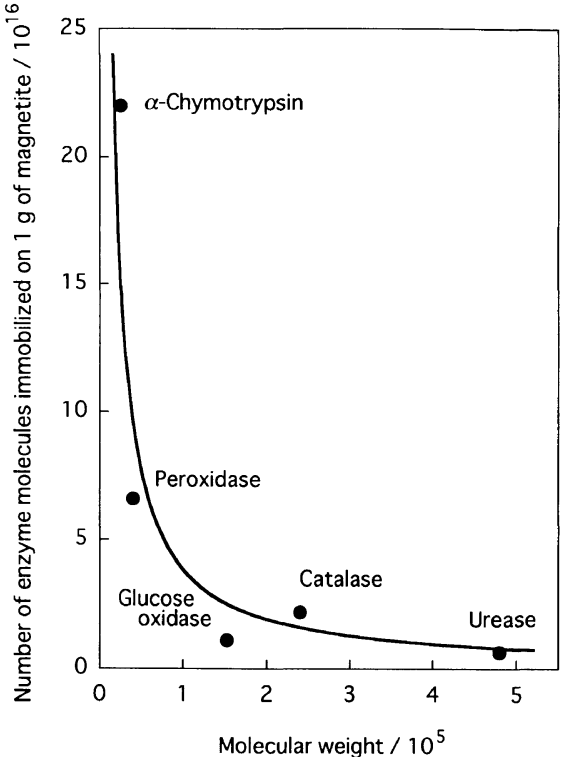

Figure 1. Relation between molecular weight of enzyme and number of enzyme molecules immobilized on magnetite particles.

Table II. Activities of immobilized enzymes

\begin{tabular}{ll}
\hline Immobilized enzyme & Relative activity $^{\text {a }}$ \\
\hline$\alpha$-Chymotrypsin & 0.76 \\
Peroxidase & 0.30 \\
Glucose oxidase & 0.49 \\
Catalase & 4.0 \\
Urease & 0 \\
\hline
\end{tabular}

${ }^{\mathrm{a}}$ Relative activity $=\frac{\text { Activity of immobilized enzyme }\left(\mathrm{Umg}^{-1}\right)}{\text { Activity of native enzyme }\left(\mathrm{U} \mathrm{mg}^{-1}\right)}$.

Figure 1. The number of immobilized enzyme molecules decreased with increasing molecular weight. Packing density near $2.2 \times 10^{-3} \mathrm{~nm}^{3}$ dalton $^{-1}$ is commonly observed for such globular proteins as enzymes. ${ }^{10-12}$ On the basis of this value, it can be estimated that each molecule of $\alpha$-chymotrypsin, peroxidase, glucose oxidase, catalase, and urease occupies a volume of $55,80,350$, 530 , and $1060 \mathrm{~nm}^{3}$, respectively. If the enzyme molecules have spherical shapes and magnetite particles are covered with close-packed monolayers of enzyme molecules, the number of enzyme molecules on $1 \mathrm{~g}$ of magnetite particles can be calculated as $3.8 \times 10^{17}, 3.0 \times 10^{17}, 1.1 \times 10^{17}$, $8.2 \times 10^{16}$, and $5.1 \times 10^{16}$, respectively. The corresponding data in Figure 1 are $10-58 \%$ of these values.
The activities of the immobilized enzymes are summarized in Table II, where the the ratio of the activity of immobilized enzyme to that of native one is given as relative activity. As for $\alpha$-chymotrypsin, peroxidase and glucose oxidase, the immobilization caused decrease in activity. A previous publication ${ }^{5}$ discussed the kinetic effects of the immobilization of glucose oxidase assuming that the glucose oxidation with the enzyme proceeds through a Michaelis-Menten mechanism as

$$
\mathrm{E}+\mathrm{S} \underset{k_{2}}{\stackrel{k_{1}}{\rightleftarrows}} \mathrm{ES} \stackrel{k_{3}}{\longrightarrow} \mathrm{E}+\mathrm{P}
$$

where $\mathrm{E}, \mathrm{S}, \mathrm{ES}$, and $\mathrm{P}$ are the enzyme, substrate $(\beta$ D-glucose), enzyme-substrate complex and product (Dglucono- $\delta$-lactone), respectively. The decrease of activity of glucose oxidase by immobilization was attributed to decrease of the rate constant $k_{3}$. Decrease of the rate constant $k_{1}$, due to limited accessibility of substrate molecules to active sites of the immobilized enzyme, was suggested, as may also be the case for $\alpha$-chymotrypsin and peroxidase. By immobilization, the activity of catalase remarkably increased and that of urease was completely lost. Although the reasons for these results are matters for argument, it is a point of interest that the activity of catalase increases by covalent immobilization on magnetite particles.

\section{REFERENCES}

1. W. F. Line, A. Kwong, and H. H. Weetall, Biochim. Biophys. Acta, 242, 194 (1971).

2. G. Baum, F. B. Ward, and H. H. Weetall, Biochim. Biophys. Acta, 268, 411 (1972).

3. F. Borrego, M. Tari, A. Manjon, and J. L. Iborra, Appl. Biochem. Biotechnol., 22, 129 (1989).

4. M. Shimomura, H. Kikuchi, H. Matsumoto, T. Yamauchi, and S. Miyauchi, Polym. J., 27, 974 (1995).

5. M. Shimomura, H. Kikuchi, T. Yamauchi, and S. Miyauchi, $J$. Macromol. Sci., Pure Appl. Chem., A33, 1687 (1996).

6. N. Tsubokawa, K. Maruyama, Y. Sone, and M. Shimomura Polym. J., 21, 475 (1989).

7. K. Mosbach, Acta Chem. Scand., 24, 2084 (1970).

8. O. H. Lowry, N. J. Rosebrough, A. L. Farr, and R. J. Randall, J. Biol. Chem., 193, 265 (1951).

9. P. Trinder, Ann. Clin. Biochem., 6, 24 (1969)

10. B. W. Matthews, J. Mol. Biol., 33, 491 (1968).

11. J. Hendle, H.- J. Hecht, H. M. Kalisz, R. D. Schmid, and D. Schomburg, J. Mol. Biol., 223, 1167 (1992).

12. N. Kunishima, K. Fukuyama, S. Wakabayashi, M. Sumida, M. Takaya, Y. Shibano, T. Amachi, and H. Matsubara, Proteins: Struct. Funct. Genet., 15, 216 (1993). 